\title{
DECOLONIZING AFRICAN STUDIES
}

As we launch the third issue of volume 61 of the African Studies Review, the editorial leadership has turned its attention to the capacity of scholarly journals to make a meaningful contribution to debates about the decolonization of Africanist knowledge. As a group of likeminded and engaged scholars we are critically aware of the place of journals in cultivating new talent and showcasing emerging scholarship. The PEASS workshops [https://africanstudies.org/peass-workshops/], now in their fourth installment, are one earnest attempt to engage with these important but often marginalized members of our community of scholars. Indeed, the ASR has since its inception occupied a preeminent location in the celebration of African and Africanist achievement, and it is with these thoughts in mind that we have embarked on two important initiatives broadly situated within the emerging knowledge decolonization paradigm. The first is to transform access to the journal on the continent with the goal of increasing engagement, usage, citation, and circulation among Africa-based scholars. The second seeks to expand our reviewing framework and network, broadening the reach of the journal, expanding inclusivity, and renewing our commitment to the vast and diverse constituencies that comprise African studies and the membership of the African Studies Association and our sister and brother networks in Canada and Europe and on the continent.

Today, perhaps more than ever, decolonizing knowledge production is a persuasive and prescient rhetoric. Just as Budd L. Hall and Rajesh Tandon (2017:7) argue that the "knowledge in the universities of our world represents a very small proportion of the global treasury of knowledge," so too the knowledge published within the pages of scholarly journals, such as the $A S R$, only represents a narrow selection of the vast new original research conducted about and on the African continent. As editors we seek to develop a deeper understanding of "other epistemologies and other ways of representing knowledge" (Hall \& Tandon 2017:7) and to challenge ourselves to draw these knowledges into the purview of our readership. The questions and debates in which we are thus ensconced are many, overlapping, and profound; several loom large with respect to scholarly journals. As editors,

African Studies Review, Volume 61, Number 3 (September 2018), pp. 1-7

(C) African Studies Association, 2018

doi:10.1017/asr.2018.97 
we might ask who produces and transmits knowledge and understanding? How might institutions such as journals and professional societies challenge hegemonic knowledge and support the production of counter-hegemonic knowledge and understanding? What role do institutions play in the cultivation and validation of new, diverse, and critical knowledges? Or what capacity do journals and journal editorial teams have to challenge existing forms of cultural, social, philosophical, and politico-economic power relations?

Some scholars have surely challenged this outlook, observing that the Western European knowledge paradigm-with its universities, journals, and professional hierarchies-is itself a hybrid knowledge environment comprised of the legacies of centuries of cultural interplay across oceans and continents (e.g., Altbach 1998). Yet even so, as Francis Adyanga Akena (2012) observes, there is a powerful and persistent relationship between knowledge producers and the motives of the societies that they inhabit. Dominant groups produce subjective knowledge to instantiate and reinstantiate socioeconomic and political perspectives. Achille Mbembe (2015) cautioned us to be vigilant to the ways in which the corrosive "myth" and "entrapment" of whiteness shapes and distorts ways of knowing in post-apartheid South Africa; decolonizing knowledge for Mbembe requires explicitly "decommissioning" the "countless" vehicles of privilege that constitute the institutions of the academy, and changing the "iconography," the symbolic economy, upon which scholarly knowledge was founded. It is with these questions and debates in mind that we have set upon several initiatives that we hope will spearhead the capacity of the ASR to contribute to the decolonization of Africanist knowledge production.

Access to the ASR on the African continent has been forefront in the minds of the editors for many years. Over the past decade or more, a number of initiatives-public, non-profit, and public/private partnerships-have sought to increase digital access, increase bandwidth, and sponsor digital journal licensing, with various degrees of success. While there are still a number of countries and tertiary institutions that suffer from poor, irregular, or nonexistent digital access to the ASR and other Africanist journals, in-house digital download metadata, as well as word-of-mouth, demonstrate that more university communities than ever before are able to read new issues and new articles. Notwithstanding, this data also demonstrate that on an individual level, and particularly in francophone and lusophone Africa, access remains a persistent problem.

To mitigate this, the ASR in collaboration with our publisher, Cambridge University Press, will soon be unveiling a new incentive mechanism to increase access to individual scholars. Starting in 2019, subject to terms and eligibility, scholars who deliver to us a peer evaluation of an article will become eligible for a courtesy coupon for free unlimited access for six months to some of the Africanist journals housed in CambridgeCore, including ASR and History in Africa. It is our hope that this incentive structure 
will propel Africa-based scholars to register and establish a complete profile in CambridgeCore. Upon selection as a peer-reviewer for an ASR submission, scholars will have the opportunity to learn the workings of the journal review system from the inside. And upon completion, they will attain unparalleled access to new African studies scholarship. It is our hope that this will also have the further effect of encouraging more Africa-based scholars to submit their original work for consideration for publication.

Our second initiative focuses on the crucial role of book reviewing. Over the past several decades the number of books reviewed has remained relatively stable at between fifty and seventy per year. This number has been determined largely by the print format of the journal as well as by limitations of space and word counts and a pre-digital assignment process. Unrelated to this, however, but during the same period, the number of quality African studies monograph and anthology publications has grown massively, in tandem with a commensurate rise in African Studies association membership around the globe. Last year the book review editors received more than four hundred volumes for review. As an editorial team, we no longer deem it sustainable or credible to review less than twenty percent of the annual scholarly production, irrespective of the merit of the work, or to engage but a tiny fraction of the ASA membership in the reviewing of new work.

Our redesigned, diversified, and expanded review team has developed a model conducive to the expansion of African studies globally and the decolonization of knowledge dissemination. We will no longer make a first determination about the relative worthiness of books to review; instead we are experimenting with a crowdsourced approach. By embracing the full set of utilities offered by our digital platform, ScholarOne, we now enter all African studies books received into the prospective review list. An initial selection of four or five scholars are invited, one at a time, in an effort to locate willing reviewers for all critical and engaged new scholarship. Our goal is to dramatically increase the number of book reviews: we want more reviews, more diverse reviewers, and we also seek to be inclusive of anglophone, lusophone, and francophone African studies scholarship. We are interested in bringing to the attention of our readership books published in African languages, and to become the premier North American scholarly journal reviewing published research emanating from the African continent. As we pursue inclusive excellence in the scholarly articles and reviews we publish, we also want to reiterate our commitment to publishing film reviews written by scholars across disciplines, living on the continent and elsewhere. Expertise in film is not required to write a review. The journal is the African Studies Review, after all; we owe it to our membership and our readership to be actively engaging with as much new publication in African studies as possible.

We hope these improvements meet with your approval, and as always, we welcome your feedback. The ASR editorial team desires to attract, review, and publish the best new research and scholarship in African studies from 
around the globe. With your continued support and engagement, we will ensure the continuity and growth of the flagship journal of the African Studies Association (USA).

This issue offers a compelling selection of disciplinary research, ranging from sociocultural anthropology and political science to history and film studies. Our contributors explore case studies in Burkina Faso, Chad, Ghana, Nigeria, Sierra Leone, Somalia, South Africa, Zimbabwe, as well as on the African continent and from interdisciplinary African studies writ large.

We open this issue with the presidential address of ASA's Past President, M. Anne Pitcher. In Chicago in 2017, Professor Pitcher delivered a keynote with the title "The ASA at 60: Advocacy in an Age of Tyranny" [https://doi. org/10.1017/asr.2018.79]. Reflecting on the foundational debates of our organization over six decades ago, Pitcher finds powerful echoes in the contemporary period, in particular the rising authoritarianism, increasing intolerance, and emboldened nativism here in the U.S. and beyond. Just as incivility, bigotry, and injustice are now the order of the day at home, Pitcher turns to the important ways in which Africans contested political restrictions in newly independent states. She asks us to find inspiration in the decolonizing world as we fine-tune our own forms of political advocacy in an epoch of illiberalism.

The second article, entitled "More than Elections: Rural Support and Regime Stability in Africa," [https://doi.org/10.1017/asr.2018.36] by Beth S. Rabinowitz, explores the significance of rural constituents for governmental stability in sub-Saharan Africa. Building on literature that identifies rural communities as key to electoral success, Rabinowitz contends that neglect of rural politics on regime stability is misguided. In Ghana, under the constitution introduced by former President J.J. Rawlings, support for rural areas reveals itself to be a factor in staving off military coups. In a country with a long and brutal history of military dictatorship, counterintuitively, the suppression of urban demands provides a foundation for political and constitutional stability. She analyzes decision-making by regimes, employing a methodology known as process-tracing, to identify regime success predictors.

The next six articles constitute an interdisciplinary forum on the history and anthropology of crime and punishment, assembled and introduced by Luise White and Todd Leedy of the University of Florida [https://doi. org/10.1017/asr.2018.86]. This forum examines two sets of debates about criminality and procedures surrounding crime: the first concerns the complexities of court testimony, consisting of articles by Katrina Keefer, Allison Shutt, and Samuel Fury Childs Daly; the second explores crime in a world where courts are nonexistent or provide inadequate access or remedy, and consists of articles by Jonny Steinberg, Judith Scheele, and Francis Musoni. Collectively, the essays force us to rethink the complications and incongruities of colonial and postcolonial crime and to question the very nature of what is labeled criminality in Africa. 
Katrina H.B. Keefer's essay, "Poro on Trial: The 1913 Special Commission Court case of Rex v. Fino, Bofio and Kalfalla," [https://doi.org/10.1017/ asr.2018.6] offers a close reading of a trial of members of a secret society in early twentieth-century Sierra Leone. Keefer's rich archival research highlights how the British colonial state conflated the Human Leopard Society with regional iterations of Poro. Keefer tackles the difficult issue of motivation for murder and reads the court transcript's representations of criminality against the legacy of slavery in the sub-region.

In colonial Southern Rhodesia, Allison K. Shutt examines the role of courts in establishing the crime of defamation. Honor and shame have a rich history in British colonial Africa, but the importation of colonial values had unforeseen consequences in settler states. In "Litigating Honor, Defamation, and Shame in Southern Rhodesia," [https://doi.org/10.1017/ asr.2018.27] Shutt explores two precedential cases that both established and narrowed the ability of litigants to sue for defamation. She argues that just as the testimony and evidence introduced in the courts jarred with received racial and social hierarchies and established definitions of honor, it is equally insightful for affective history. As these cases established the right of African litigants to be protected from defamation, precedents such as these paved the way for future suits by the Rhodesian emergent black professional class.

In the fragmentary court records of the short-lived secessionist Biafran republic, Samuel Fury Childs Daly explores how violent gun crimes proliferated. In "'Hell was let loose on the country': The Social History of Military Technology in the Republic of Biafra," [https:/ / doi.org/10.1017/asr.2018.41], Daly contends that armed crime in late twentieth-century Nigeria echoes events of the Nigerian Civil War (1967-1970). Court records from the Republic of Biafra may be scarce, but the wide availability of firearms and the collapsing economy gave rise to a proliferation of disputes. For Daly, the profound capacity of military technology to shape relationships, particularly in times of civil conflict, extends the life histories of gun crimes deep into the present.

Jonny Steinberg's article, "Xenophobia and Collective Violence in South Africa: A Note of Skepticism About the Scapegoat," [https://doi. org/10.1017/asr.2018.56] investigates the staggering rise in xenophobic violence in post-apartheid South Africa. How might we account for the fact that, in a country with seemingly no shortage of credible venues for criminal prosecution, the vast majority of anti-foreigner (often anti-Somali) violence is never prosecuted? Steinberg reviews some of the scholarly debates surrounding this and related issues and sees perceptions about the decline in sovereign power and theatrical violence as attempts to resuscitate that power as inadequate, insofar as they scapegoat victims of individuated and collective violence.

In "Ravens Reconsidered: Raiding and Theft Among Tubu-Speakers in Northern Chad," [https://doi.org/10.1017/asr.2018.34] Judith Scheele examines another space of perceived lawlessness. The alleged predilection 
of Chadians for looting and theft offers an opportunity to interrogate what Scheele calls a "rhetoric of predation." Far from simple criminality, however, she contends that cultural practices such as cattle-raiding for bridewealth upend received wisdom about what constitutes crime. Scheele sees a quest for personal autonomy as one of several inadequately theorized social forces that challenge notions of crime in unpoliced regions of the Sahel.

With the final article in the crime and punishment forum, Francis Musoni asks us to rethink practices and policies surrounding what is often referred to as illegal migration. In "The Ban on 'Tropical Natives' and the Promotion of Illegal Migration in Pre-Apartheid South Africa" [https:/ / doi.org/10.1017/asr.2018.73], Musoni reinterprets South Africa's ill-fated 1913 ban on the recruitment of migrant workers. While the policy criminalized employment of "tropical natives" within the Union, its poor articulation and piecemeal implementation had unforeseen consequence. Farmers and industrialists contested the ban, and illegal migration increased. By the time the ban was lifted, migratory movements from Southern Rhodesia were creating new headaches. Contemporary post-apartheid South Africa's "illegal migration" debate might look to historical failures to control African mobility in its effort to understand the forces that make people move.

Thanks to the nimble stewardship of one of our film review editors, Ken Harrow, we are also thrilled to be able to bring before our members a special celebration of the life and work of distinguished Burkinabé filmmaker Idrissa Ouedraogo, who died earlier this year. Ouedraogo is perhaps best known outside Africanist circles for his feature film "Tilaï," which co-won the 1990 Cannes Film Festival Grand Prix with Kōhei Oguri's "Shi no toge," and for "Samba Traoré" (1993), which won the Silver Bear award at the 43rd Berlin International Film Festival. Ouedraogo yearned for a truly African film aesthetic: as a key pioneer of the second wave of independent Africain cinema, he championed resistance cinema and dared to imagine the liberation of unique and authentic African voices unfettered by the constraints of industry, commerce, and finance. He was no naïve romantic, but rather represented social, family, and community issues with a very human face. For Africanists, Ouedraogo remains a treasured and celebrated figure, as Ken Harrow's introduction [https://doi.org/10.1017/asr.2018.72] to the collection of original reflections along with reprinted interviews and translated articles makes clear.

Our issue concludes with an excellent selection of review essays and film and book reviews. Both review essays are representative of the journal's concerted attempt to broaden the remit of the reviewing process and draw back neglected readership in the many and diverse subfields of African studies. Pascal James Imperato [https://doi.org/10.1017/asr.2018.67] brings to our attention the remarkable photographic contributions of Solomon Osagie Alonge, Sammy Baloji, Mohamed Camara, Saidou Dicko, and George Osodi. And Brian Stanley's [https:/ / doi.org/10.1017/asr.2018.88] essay showcases new research on Christian revivals in East Africa. With the exception of the Ouedraogo forum, all the original scholarly articles 
appearing in this issue originated under the previous editorial leadership of Sean Redding and Elliot Fratkin, and we thank them for continued engagement with the journal's activities.

\section{References}

Akena, Francis Adyanga. 2012. "Critical Analysis of the Production of Western Knowledge and Its Implications for Indigenous Knowledge and Decolonization." Journal of Black Studies Vol. 43 (6): 599-619.

Altbach, Philip G. 1998. Comparative Higher Education: Knowledge, the University, and Development. Westport CT: Greenwood Publishing Group.

Hall, B. L. and R. Tandon. 2017. "Decolonization of knowledge, epistemicide, participatory research and higher education." Research for All 1 (1): 6-19. DOI 10.18546/RFA.01.1.02.

Mbembe, Achille. 2015. "Decolonizing Knowledge and the Question of the Archive." Africa Is A Country eBook [https://africaisacountry.atavist.com/decolonizingknowledge-and-the-question-of-the-archive]. 